\title{
ANALISIS KEBUTUHAN TENAGA KEPERAWATAN BERBASIS BEBAN KERJA DENGAN METODE WORKLOAD INDICATOR STAFF NEED (WISN) DI INSTALASI GAWAT DARURAT (IGD) RUMAH SAKIT IBU DAN ANAK PROVINSI ACEH
}

\begin{abstract}
1| Nadia Fajri, 2| Yusni, 3|Said Usman, 4| Irwan Syahputra, 5| Nurjannah
Email : nadia.fajri80@gmail.com

ABSTRACT

Background: The problem of shortage of medical personnel must be considered properly, whether it really requires additional manpower due to excessive workloads which will affect the quality provided or the amount of unproductive time spent by HR while on duty. This also happened at the Aceh Province Mother and Child Hospital, there are plans to increase the number of staff carried out at the Mother and Child Hospital who need to use workload calculations, the reality on the ground is that the planning of medical personnel in RSIA is only based on the request of the work unit and the comparison of calculations between the number of medical personnel with BOR, LOS and others or because of the increase in the class of the hospital and the lack of qualifications of each type of medical staff. Objective: to analyze the need for workload-based nursing personnel using the Workload Indicator Staff Need (WISN) method in the Emergency Departments (ED) Mother and Child Hospital, Aceh Province. Research Methods: This research is a descriptive study, using a work sampling method, namely all the activities of nurses who served in the IGD RSIA Aceh Province as respondents who were examined every time for four days. The population in this study were all nurses in the Emergency Departments (ED) of the Aceh Province Hospital in 2020 totaling 19 people, the samples in this study were all nurses in the Emergency Departments (ED) with a total sampling of 19 people. The calculation of the need for nurses using the WISN method. Results: the workload of health workers in RSIA Aceh Province can be seen from the details / job descriptions of the job, the amount of time required for each task, the time for completing tasks is a multiplication of the workload with the norm of time and the number of hours of effective working time. Besides being influenced by the number of workers, the workload of health workers can also be influenced by the number of patients and the conditions of the workplace environment. Conclusion: the results of the WISN calculation show that the health personnel at RSIA Provini Aceh still lacks 1 nurse in the ED. The shortage of health workers will have an impact on the high workload of health workers in each sector.
\end{abstract}

ARTICLE INFO

Keywords:

Nursing Personnel Needs;

Workload; WISN

\section{Pendahuluan}

Rumah sakit menjadi salah satu instansi kesehatan yang dalam pelaksanaannya dapat dijalankan oleh pemerintah maupun swasta dimana salah satu fungsinya adalah meningkatkan kesehatan masyarakat dari tiga aspek utama yaitu pencegahan, pengobatan dan rehabilitatif, kegiatan tersebut semua dilakukan atas dasar kemanusiaan dan untuk mengurangi dampak resiko penyebaran penyakit dari dan untuk manusia. Rumah sakit dalam pengoperasiannya melibatkan seluruh aspek terutama yang menyangkut seluruh elemen sumber daya manusia dari berbagai keahlian. Untuk itu pelayanan rumah sakit dangat berkaitan dengan tersedia tidaknya sarana dan prasarana serta sumber daya manusia yang ada di rumah sakit tersebut (1)

Kendala dalam pelaksanaan pelayanan kesehatan adalah ketidakcocokan jumlah staf dengan beban kerja yang ada. ini karena jumlah keahlian staf belum proporsional, atau karena distribusi staf masih belum didasarkan pada kebutuhan nyata atau beban kerja di lapangan. Penumpukan staf dalam satu unit tanpa kerja yang jelas, dan kurangnya staf di unit lain merupakan masalah. Salah satu solusi untuk mengatasi ini adalah dengan menghitung jumlah kebutuhan daya yang optimal berdasarkan beban kerja nyata.

Ketersediaan sumber daya manusia rumah sakit disesuaikan dengan kebutuhan rumah sakit berdasarkan jenis rumah sakit dan layanan yang diberikan kepada masyarakat. Masalah yang sering terjadi dalam organisasi adalah kurangnya jumlah dan jenis staf yang dibutuhkan, kurangnya kompetensi (pengetahuan, keterampilan, sikap dan nilai-nilai) dan keterbatasan dana dari Rumah Sakit sehingga mereka tidak dapat menambah dan merawat SDM yang mereka butuhkan (2)

Terdapat dua hal yang menjadi dasar sumber daya manusia di rumah sakit untuk dipertimbangkan, pertama, produk yang ditawarkan di rumah sakit adalah layanan yang sangat

\footnotetext{
${ }^{5}$ Program Studi Magister Kesehatan Masyarakat Fakultas Kedokteran Universitas Syiah Kuala
} 
Nadia Fajri, Yusni, Said Usman, Irwan Syahputra, Nurjannah: Analisis kebutuhan tenaga keperawatan berbasis beban kerja dengan metode workload indicator staff need (WISN) di instalasi gawat darurat (IGD) rumah sakit ibu dan anak Provinsi Aceh. Jurnal Kesehatan. Vol 13 (2) 2020

padat karya, sehingga peran energi sangat besar, kurangnya manusia sumber daya atau tenaga kerja yang baik dalam bentuk kuantitas dan kualitas akan mempengaruhi kualitas produk yang dihasilkan, sehingga berdampak pada citra rumah sakit dan mengurangi manfaat rumah sakit. Kedua, energi adalah energi yang tidak dapat diperoleh secara instan walaupun harus ada penyesuaian sebelum dapat digunakan secara optimal untuk meningkatkan kesehatan dan mengurangi morbiditas (3)

Meningkatnya morbiditas dan munculnya berbagai penyakit baru yang muncul dan penyakit eemeging adalah penyebab yang membutuhkan lebih banyak kewaspadaan dan mempersiapkan petugas kesehatan yang andal dengan kuantitas dan kualitas yang memadai serta mengikuti perkembangan dunia kesehatan. Meskipun indikator kesehatan di Indonesia tampaknya membaik, status kesehatan di Indonesia masih tertinggal jika dibandingkan dengan negaranegara Asia Tenggara, karena fasilitas kesehatan yang tidak efisien dan jumlah pekerja yang tidak memenuhi kebutuhan, itu adalah Lebih lanjut dinyatakan bahwa secara bertahap pemenuhan kebutuhan energi kesehatan terus dilakukan untuk pemenuhan dan pemerataan tenaga medis terutama di daerah terpencil, sangat terpencil bahkan di daerah perbatasan (4)

Masalah kekurangan tenaga medis harus terus dipertimbangkan dengan baik, apakah itu benarbenar membutuhkan tenaga tambahan karena beban kerja yang berlebihan yang akan mempengaruhi kualitas yang disediakan atau jumlah waktu tidak produktif yang dihabiskan oleh SDM saat bertugas. Ini juga terjadi di Rumah Sakit Ibu dan Anak Provinsi Aceh, ada rencana untuk meningkatkan jumlah staf yang dilakukan di Rumah Sakit Ibu dan Anak yang perlu menggunakan perhitungan beban kerja, kenyataan di lapangan bahwa perencanaan tenaga medis di RSIA hanya berdasarkan permintaan unit kerja dan perbandingan perhitungan antara jumlah tenaga medis dengan BOR, LOS dan lainnya atau karena peningkatan kelas rumah sakit dan kurangnya kualifikasi masing-masing jenis staf medis (5)

Hasil penelitian yang dilakukan di RSUD Bekasi tentang Analisis Beban Kerja dan Kebutuhan Tenaga Perawat diperoleh hasil penelitian bahwa standar beban kerja dihitung berdasarkan penggunaan waktu kegiatan keperawatan langsung sebagai kegiatan pokok perawat. Total kebutuhan tenaga perawat di Instalasi Rawat Inap Tulip berdasakan WISN adalah 45 tenaga dengan Rasio WISN 0.8. Dari Rasio WISN dapat disimpulkan bahwa tenaga saat ini lebih kecil dibandingkan dengan jumlah tenaga dibutuhkan untuk menjalankan beban kerja yang ada. Perlu adanya penambahan tenaga sebanyak 10 orang dari jumlah tenaga yang ada sebanyak 35 orang untuk mencapai keadaan seimbang (6)

Rumah Sakit Ibu dan Anak adalah salah satu rumah sakit pemerintah di Banda Aceh dan khususnya memberikan layanan kepada ibu dan anak. Berdasarkan data yang diperoleh dari Registrasi Medis Rumah Sakit Ibu dan Anak Pemerintah Aceh (RSIA) (yang sekarang dikategorikan sebagai rumah sakit tipe B khusus) di kamar rawat inap ibu, kamar rawat inap untuk anak-anak, kamar VIP, kamar NICU / PICU dan Kamar kelas I.

Berdasarkan data kunjungan dari tahun 2017 terdapat 112.116 kunjungan pasien baru dan 143.557 kunjungan pasien lama, pada tahun 2018 terdapat 120.177 kunjungan pasien baru dan 146.786 kunjungan pasien lama dan pada 2019 terdapat 125.139 orang kunjungan pasien baru dan 149.651 jumlah kunjungan pasien lama. Dengan meningkatnya jumlah pasien, tenaga perawat yang bertugas kewalahan untuk memberikan layanan. Karena di RSIA setiap shift (tim) hanya ada 4 orang di pagi hari, 2 orang di sore hari, 2 orang di malam hari. Waktu kerja perawat dibagi menjadi 3 (tiga) shift, yaitu shift pagi (08.00-14.00), shift sore (14.00-20.00) dan shift malam (20.00-08.00). Di pagi dan sore hari jumlah kunjungan jauh dibandingkan dengan jumlah kunjungan di malam hari. Namun, jumlah perawat di pagi hari sudah cukup dalam hal penanganan pasien yaitu 4 orang.

Dengan pembagian jumlah perawat tersebut diketahui bahwa adanya beban kerja yang tinggi karena kadang-kadang waktu kerja yang berlebihan, bagaimana lagi jika ada petugas yang mengambil cuti tahunan dan cuti hamil ini disebabkan karena banyaknya pasien yang masuk, 
belum lagi jika ada kejadian luar biasa seperti keracunan massal sehingga penanganannya membutuhkan waktu ekstra. Dengan kondisi seperti itu, beban kerja tenaga perawat yang memasuki shift pagi meningkat, meskipun shift sore dokter sudah tiba tetapi masih kewalahan dalam menjalankan tugasnya sehingga dokter shift pagi, yang waktu kerjanya 08: 00-14: 00 tapi tetap bekerja sampai jam 15:00-16:00

Penelitian yang berjudul workload, well being and career satisfaction among french internal medicine physician and resident in 2018 menyimpulkan bahwa $66 \%$ responden puas dengan pekerjaan mereka, dan $62 \%$ akan memilih spesialisasi penyakit dalam lain. Namun, $71 \%$ responden bekerja lebih dari 50 jam seminggu, 21\% bekerja lebih dari 60 jam seminggu dan $70 \%$ percaya bahwa mereka tidak punya cukup waktu untuk kegiatan pribadi / keluarga. 25\% dari responden memiliki setidaknya satu tanda kelelahan $(19 \%$ dari dokter dalam praktek dan $32 \%$ dari penduduk (7)

Penelitian lain yang dilakukan Di Rumah Sakiat Hasan Sadikin bandung menyimpulkan bahwa dengan metode perhitungan yang ada masih kekurangan 42

perawat. Kegiatan produktif membutuhkan waktu $75,64 \%$ dan dalam kategori tinggi. Perhitungan kebutuhan tenaga perawat berdasarkan metode WISN adalah 104 tenaga perawat dengan rasio WISN 0,6 (8)

Menurut hasil survey pendahuluan yang dilakukan pada perawat RSIA pemerintah Aceh yang berjumlah 14 orang. Dari 14 orang tersebut yang telah diwawancarai rata-rata mengalami kelebihan beban kerja. Disamping itu kondisi kerja yang kurang menyenangkan seperti kebisingan, ruangan panas, banyaknya keluarga pasien yang berkunjung serta tidak adanya keharmonisan antara teman sejawat, kurang lengkapnya fasilitas seperti ruang tindakan diyakini juga dapat mengganggu iklim kerja dan akan berdampak pada menurunnya dalam memberikan tindakan kepada klien. Beban kerja petugas medis juga dapat dilihat dari Bed Occupacy Rate (BOR), bila BOR diatas $80 \%$ kegiatan rawat inap sangat padat sedangkan bila BOR dibawah $50 \%$ berarti tempat tidur yang tersedia belum dimanfaatkan sebagaimana mestinya. Tingginya persentase BOR dapat menyebabkan dokter harus bekerja lebih lama dari jadwal yang ditentukan apalagi sumber daya dokter yang ada di Rumah Sakit Ibu dan Anak masih sangat terbatas.

\section{Metode Penelitian}

Penelitian ini merupakan penelitian deskriptif, menggunakan metode work sampling, yaitu seluruh aktivitas perawat yang bertugas di IGD RSIA Provinsi Aceh sebagai responden yang diteliti selama empat hari. Penelitiannya ini nantinya akan menghasilkan jumlah optimal tenaga keperawatan di Unit Intensif Gawat Darurat (IGD) RSIA Provinsi Aceh yang diteliti menggunakan metode Workload Indicator Staff Needs (WISN)

Populasi dalam penelitian ini adalah seluruh perawat yang berada di unit Intensif Gawat Darurat (IGD) RSIA Provinsi Aceh Tahun 2020 berjumlah 19 orang. Analisis data kuantitatif dilakukan dengan menggunakan perhitungan WISN.

\section{Hasil Penelitian}

\section{Jumlah Perawat Per Shift}

Tabel 1. Distribusi Jumlah Perawat Per shift dan Jumlah Kunjungan Pasien di IGD RSIA Provinsi Aceh

\begin{tabular}{|c|c|c|c|c|c|c|c|c|c|}
\hline \multirow[b]{2}{*}{ Tanggal } & \multicolumn{3}{|c|}{ Shift Pagi } & \multicolumn{3}{|c|}{ Shift Siang } & \multicolumn{3}{|c|}{ Shift malam } \\
\hline & $\begin{array}{l}\text { Jumlah } \\
\text { Perawat }\end{array}$ & $\begin{array}{l}\text { Jumlah } \\
\text { Pasien }\end{array}$ & $\begin{array}{c}\text { Klasifika } \\
\text { si } \\
\text { Pasien }\end{array}$ & $\begin{array}{l}\text { Jumlah } \\
\text { Perawat }\end{array}$ & $\begin{array}{l}\text { Jumlah } \\
\text { Pasien }\end{array}$ & $\begin{array}{c}\text { Klasifika } \\
\text { si } \\
\text { Pasien }\end{array}$ & $\begin{array}{l}\text { Jumlah } \\
\text { Perawat }\end{array}$ & $\begin{array}{l}\text { Jumlah } \\
\text { Pasien }\end{array}$ & $\begin{array}{c}\text { Klasifik } \\
\text { asi } \\
\text { Pasien }\end{array}$ \\
\hline
\end{tabular}


Nadia Fajri, Yusni, Said Usman, Irwan Syahputra, Nurjannah: Analisis kebutuhan tenaga keperawatan berbasis beban kerja dengan metode workload indicator staff need (WISN) di instalasi gawat darurat (IGD) rumah sakit ibu dan anak Provinsi Aceh. Jurnal Kesehatan. Vol 13 (2) 2020

\begin{tabular}{|c|c|c|c|c|c|c|c|c|c|}
\hline $07 / 07 / 2020$ & 8 & 36 & $\begin{array}{c}\mathrm{A} 1=14 \\
\mathrm{~A} 2=13 \\
\mathrm{~A} 3=9\end{array}$ & 5 & 25 & $\begin{array}{c}\mathrm{A} 1=5 \\
\mathrm{~A} 2=12 \\
\mathrm{~A} 3=8\end{array}$ & 4 & 20 & $\begin{array}{l}\mathrm{A} 1=3 \\
\mathrm{~A} 2=9 \\
\mathrm{~A} 3=8\end{array}$ \\
\hline 08/07/2020 & 10 & 33 & $\begin{array}{c}\mathrm{A} 1=6 \\
\mathrm{~A} 2=14 \\
\mathrm{~A} 3=13\end{array}$ & 4 & 15 & $\begin{array}{l}\mathrm{A} 1=3 \\
\mathrm{~A} 2=5 \\
\mathrm{~A} 3=7\end{array}$ & 5 & 17 & $\begin{array}{l}\mathrm{A} 1=5 \\
\mathrm{~A} 2=7 \\
\mathrm{~A} 3=5\end{array}$ \\
\hline $09 / 07 / 2020$ & 9 & 38 & $\begin{aligned} \mathrm{A} 1 & =8 \\
\mathrm{~A} 2 & =21 \\
\mathrm{~A} 3 & =9\end{aligned}$ & 7 & 18 & $\begin{array}{l}\mathrm{A} 1=4 \\
\mathrm{~A} 2=9 \\
\mathrm{~A} 3=5\end{array}$ & 3 & 14 & $\begin{array}{l}\mathrm{A} 1=3 \\
\mathrm{~A} 2=7 \\
\mathrm{~A} 3=4\end{array}$ \\
\hline $10 / 07 / 2020$ & 11 & 41 & $\begin{array}{l}\mathrm{A} 1=15 \\
\mathrm{~A} 2=11 \\
\mathrm{~A} 3=15\end{array}$ & 5 & 13 & $\begin{array}{l}\mathrm{A} 1=3 \\
\mathrm{~A} 2=7 \\
\mathrm{~A} 3=3\end{array}$ & 3 & 13 & $\begin{array}{l}\mathrm{A} 1=3 \\
\mathrm{~A} 2=8 \\
\mathrm{~A} 3=2\end{array}$ \\
\hline
\end{tabular}

Sumber : Data Primer Diolah (2020)

Tabel 4.1 menjelaskan bahwa pada shift pagi perawat yang bertugas rata-rata 8-11 orang dengan jumlah pasien berkisar antara 33-41 orang, rata rata klasifikasi pasien adalah A2 yaitu pasien kasus mendesak yaitu pasien yang berada dalam keadaan gawat tetapi tidak mengancam nyawanya dan anggota badannya. Pada shift siang rata-rata jumlah perawat yang bertugas adalah 4-7 orang dengan jumlah pasien berkisar antara 13-25 orang, jenis pasien rata-rata adalah A2 yaitu pasien kasus mendesak yaitu pasien yang berada dalam keadaan gawat tetapi tidak mengancam nyawanya dan anggota badannya. Pada shift malam rata-rata jumlah perawat yang bertugas adalah 3-5 orang dengan jumlah pasien berkisar antara 13-20 orang, dan jenis pasien rata-rata adalah A2 yaitu pasien kasus mendesak yaitu pasien yang berada dalam keadaan gawat tetapi tidak mengancam nyawanya dan anggota badannya.

\section{Karakteristik Responden}

Penelitian dilaksanakan dari tanggal 07 hingga 10 Juli 2020. Pelaksanaan penelitian ini, dibantu oleh beberapa pihak antara lain dari pihak manajemen RSIA Provinsi Aceh. Observasi kegiatan tenaga kesehatan, peneliti menggunakan prinsip work sampling dan peneliti menggunakan prinsip work sampling untuk melakukan wawancara pada semua aktivitas yang dilakukan oleh perawat di unit IGD Rumah Sakit Ibu dan Anak Provinsi Aceh. Pada saat dilakukan penelitian di unit IGD Rumah Sakit Ibu dan Anak Provinsi Aceh terdapat 19 Responden. Karakteristik responden dapat dilihat pada Tabel 2.

Tabel 2. Karakteristik Responden Instalasi Rawat Jalan RSIA Provinsi Aceh

\begin{tabular}{|c|c|c|c|}
\hline No & Deskripsi & Jumlah & Presentase \\
\hline \multirow[t]{3}{*}{1} & Jenis Kelamin & & \\
\hline & Laki-laki & 10 & 52,6 \\
\hline & Perempuan & 9 & 47,4 \\
\hline \multirow[t]{3}{*}{2} & Umur & & \\
\hline & $20-30$ & 12 & 63,2 \\
\hline & $31-40$ & 7 & 36,8 \\
\hline \multirow[t]{3}{*}{3} & Pendidikan & & \\
\hline & D III & 11 & 57,9 \\
\hline & $\mathrm{S} 1$ & 8 & 42,1 \\
\hline \multirow[t]{3}{*}{4} & Lama Kerja (Tahun) & & \\
\hline & 1-7 tahun & 13 & 68,4 \\
\hline & 8-14 tahun & 6 & 31,6 \\
\hline
\end{tabular}




\begin{tabular}{ccc}
\hline Jumlah & 19 & 100 \\
\cline { 2 - 3 } Sumber: Data Diolah (2020)
\end{tabular}

Tabel 2 menunjukkan bahwa jumlah responden yang berjenis kelamin laki-laki (52,6\%), berada pada kelompok umur 20-30 tahun $(63,28 \%)$, berpendidikan DIII $(57,9 \%)$ dan telah bekerja selama 1-7 tahun $(68,4 \%)$.

Setelah pengumpulan data primer hasil observasi dan data sekunder dari telaah dokumen rumah sakit didapatkan, peneliti juga melakukan wawancara mendalam dengan bagian kepegawaian RSIA Provinsi Aceh. Dalam melakukan wawancara, peneliti mengajukan beberapa pertanyaan. Pada saat wawancara mendalam informan dapat menjawab dengan lancar dan nyaman sesuai dengan pertanyaan yang diajukan tentang SDM di RSIA Provinsi Aceh

\section{Waktu kerja yang tersedia/Available Working Time (AWT)}

Tenaga perawat yang bertugas di IGD RSIA Provinsi Aceh mempunyai uraian tugas yang sama dengan penyelesaian atau waktu yang digunakan berbeda masing-masing individu. Waktu kerja tersedia adalah waktu yang harus dipenuhi oleh seorang perawat dalam menjalankan kegiatan pokoknya. Menetapkan waktu kerja tersedia bertujuan untuk memperoleh waktu kerja tersedia tenaga kesehatan di RSIA Aceh dalam satu tahun. Waktu kerja di RSIA Aceh terbagi menjadi 3 shift jaga, dengan alokasi waktu shift pagi dimulai pukul $08.00-14.00$, shift sore dimulai pukul 14.00 - 20.00, dan shift malam dimulai pukul 20.00 - 08.00 hari berikutnya.

1. Hari kerja (A), sesuai kebijakan yang berlaku di RSIA Provinsi Aceh yaitu 6 hari kerja (bagi yang piket). Dalam 1 tahun 312 hari kerja ( 6 x 52 minggu).

(A) = 312 sesuai dengan hasil wawancara mendalam

“...Jumlah hari kerja perawat menggunakan 6 hari kerja per minggu, 365 hari per tahun dikurang 52 hari minggu ...

2. Cuti tahunan (B), sesuai dengan ketentuan bahwa setiap perawat memiliki hak 12 hari untuk cuti setiap tahunnya.

(B) $=12$

... hak cuti itu 12 hari per tahun, jadi sesuai dengan pemerintah ...

3. Pendidikaan dan pelatihan (C), berdasarkan data dari wawancara mendalam, setiap perawat mendapatkan 20 jam selama setahun dari luar jam kerja perawat. (C) $=3$

...untuk kegiatan diklat pagawai minimal mendapatkan 20 jam pertahun, tapi itu diambil dari luarjam kerja ..."

Hari libur nasional (D), berdasarkan keputusan menteri terkait tentang cuti bersama dan libur nasional, tahun 2019 ditetapkan 16 hari libur nasional dan 4 hari cuti bersama. (D) = 20

“...untuk cuti bersama dan libur nasional kita mengikuti edaran dari pemerintah pusat, jadi ada 20 hari libur..."

5. Ketidakhadiran kerja (E), toleransi untuk ketidakhadiran kerja ditentukan oleh penyebab ketidakhadiran kerja tersebut dan jumlah hari menyesuaikan penyebabnya.

“...untuk toleransi ketidakhadiran kerja tergantung dari penyebabnya itu sendiri, misalnya sakit ya menyesuaikan surat dari dokter, kemudian melahirkan itu 2 bulan sebelum dan 2 bulan sesudah melahirkan itu liburnya..."

Peneliti mengambil hari toleransi ketidakhadiran kerja sebanyak 14 hari, diasumsikan dalam satu bulan 1 hari izin. (E) = 14

4 Waktu kerja (F), sesuai dengan ketentuan yang berlaku di RSIA Aceh waktu kerja setiap shift dalam 1 hari adalah 8 jam. $(F)=8 j a m$. 
Nadia Fajri, Yusni, Said Usman, Irwan Syahputra, Nurjannah: Analisis kebutuhan tenaga keperawatan berbasis beban kerja dengan metode workload indicator staff need (WISN) di instalasi gawat darurat (IGD) rumah sakit ibu dan anak Provinsi Aceh. Jurnal Kesehatan. Vol 13 (2) 2020

I. Menetapkan waktu pertama kerja tersedia
A. 6 (hari kerja) x 52 ( minggu) $=312$ hari
B. 18 hari
C. 6 hari
D. 18 hari
E. 10 hari
F. 8 jam

1. Hari kerja tesedia

$$
\begin{aligned}
& =\{A-(B+C+D+E)\} \\
& =\{312-(18+6+18+10)\} \\
& =\{312-(52)\} \\
& =260 \text { hari kerja/tahun }
\end{aligned}
$$

2. Hari kerja tersedia

$=$ hari kerja tersedia $\mathrm{x} \mathrm{f}$

$=260 \times 8$ (hari kerja/tahun

$=2080 \times 60$ (jam/tahun)

$=124.800($ menit $/$ tahun

\section{Menentukan Kategori Aktivitas Keperawatan di IGD RSIA Provinsi Aceh}

\begin{tabular}{|c|c|c|c|}
\hline No & Jenis Kegiatan & $\mathrm{F}$ & $\%$ \\
\hline & Kegiatan Langsung & (menit/hr) & \\
\hline 1 & Anamnese Pasien & 213 & 1,73 \\
\hline 2 & Pemeriksaan tanda vital pasien & 281 & 2,29 \\
\hline 3 & Mengantar pasien ke ruang tindakan & 240 & 1,95 \\
\hline 4 & Memasang gelang identitas & 250 & 2,04 \\
\hline 5 & Menerima pasien baru & 224 & 1,82 \\
\hline 6 & Nebulisasi & 247 & 2,01 \\
\hline 7 & Fiksasi pasien & 230 & 1,87 \\
\hline 8 & Pasang infus & 220 & 1,79 \\
\hline 9 & Melepas infus & 291 & 2,37 \\
\hline 10 & Melepas transfusi & 240 & 1,95 \\
\hline 11 & Mengganti infus & 242 & 1,97 \\
\hline 12 & Memperbaiki infus & 209 & 1,70 \\
\hline 13 & Mendampingi visit dokter & 224 & 1,82 \\
\hline 14 & Observasi pasien & 225 & 1,83 \\
\hline 15 & Pemberian obat & 217 & 1,77 \\
\hline 16 & Pasang monitor & 294 & 2,39 \\
\hline 17 & Pasang NGT & 247 & 2,01 \\
\hline 18 & Pasang Oksigen & 212 & 1,73 \\
\hline 19 & Pemeriksaan EKG & 231 & 1,88 \\
\hline 20 & Reposisi pasien & 237 & 1,93 \\
\hline 21 & Reposisi selang oksigen & 215 & 1,75 \\
\hline 22 & Membersihkan luka & 222 & 1,81 \\
\hline
\end{tabular}

Aktivitas keperawatan tenaga perawat dibagi menjadi langsung, tidak langsung, pribadi dan non produktif. Berikut adalah tabel distribusi waktu aktifitas perawat di IGD RSIA

Tabel 3. Frekuensi Aktivitas Perawat di Unit IGD RSIA Provinsi Aceh 
Nadia Fajri, Yusni, Said Usman, Irwan Syahputra, Nurjannah: Analisis kebutuhan tenaga keperawatan berbasis beban kerja dengan metode workload indicator staff need (WISN) di instalasi gawat darurat (IGD) rumah sakit ibu dan anak Provinsi Aceh. Jurnal Kesehatan. Vol 13 (2) 2020

\begin{tabular}{|c|c|c|c|}
\hline 23 & Edukasi pasien & 287 & 2,34 \\
\hline 24 & Menyiapkan perpindahan pasien & 245 & 1,99 \\
\hline 25 & pasang kateter & 220 & 1,79 \\
\hline 26 & pasang transfusi & 227 & 1,85 \\
\hline 27 & Edukasi keluarga pasien & 251 & 2,04 \\
\hline 28 & Membuang urine pasien & 202 & 1,64 \\
\hline \multirow[t]{3}{*}{29} & informed consent & 227 & 1,85 \\
\hline & Sub Total & 6.870 & 55,94 \\
\hline & Kegiatan Tidak Langsung & & \\
\hline 1 & Menyiapkan perpindahan pasien & 240 & 1,95 \\
\hline 2 & Merapikan ruangan & 260 & 2,12 \\
\hline 3 & konsul ke dokter jaga & 230 & 1,87 \\
\hline 4 & Mengisi formulir skrining & 282 & 2,30 \\
\hline 5 & Mengisi buku register & 257 & 2,09 \\
\hline 6 & Persiapan alat & 240 & 1,95 \\
\hline 7 & Merapikan meja & 240 & 1,95 \\
\hline 8 & Operan shift & 223 & 1,82 \\
\hline 9 & Mengisi rekam medis & 294 & 2,39 \\
\hline 10 & Menyiapkan obat & 240 & 1,95 \\
\hline 11 & Merapikan berkas tindakan & 244 & 1,99 \\
\hline 12 & Merapikan troli emergency & 229 & 1,86 \\
\hline 13 & Administrasi pasien pulang & 234 & 1,91 \\
\hline \multirow[t]{3}{*}{14} & Mengambil hasil ke radiologi & 235 & 1,91 \\
\hline & Sub total & 3.448 & 28,07 \\
\hline & Kegiatan Pribadi & & \\
\hline 1 & Makan & 252 & 2,05 \\
\hline 2 & Minum & 260 & 2,12 \\
\hline 3 & Sholat & 305 & 2,48 \\
\hline \multirow[t]{3}{*}{4} & Toilet & 282 & 2,30 \\
\hline & Sub total & 1.099 & 8,95 \\
\hline & Kegiatan Non Produktif & & \\
\hline 1 & Mengobrol & 220 & 1,79 \\
\hline 2 & Menggunakan HP & 200 & 1,63 \\
\hline 3 & Membaca koran & 225 & 1,83 \\
\hline \multirow[t]{3}{*}{4} & Main game & 220 & 1,79 \\
\hline & Sub Total & 865 & 7,04 \\
\hline & Total & 12.282 & 100,00 \\
\hline
\end{tabular}

Sumber : Data Diolah (2020)

Tabel 3 menunjukkan bahwa rata-rata waktu yang diperlukan untuk melakukan kegiatan langsung adalah 6.870 menit $(55,9 \%)$, kegiatan tidak langsung 3.448 menit $(28, \%)$, kegiatan pribadi 1.099 menit $(8,9 \%)$ dan untuk kegiatan non produktif 865 menit $(7,4 \%)$. 
Nadia Fajri, Yusni, Said Usman, Irwan Syahputra, Nurjannah: Analisis kebutuhan tenaga keperawatan berbasis beban kerja dengan metode workload indicator staff need (WISN) di instalasi gawat darurat (IGD) rumah sakit ibu dan anak Provinsi Aceh. Jurnal Kesehatan. Vol 13 (2) 2020

5. Menentukan Standar beban Kerja Tenaga Keperawatan di IGD RSIA Provinsi Aceh Standar beban kerja $=\frac{\text { Waktu kerja tersedia }}{\text { Rata-rata waktu per kegiatan pokok }}$

Tabel 5. Standar Beban Kerja Tenaga Keperawatan di IGD RSIA Provinsi Aceh

\begin{tabular}{|c|c|c|c|}
\hline No & Kegiatan & $\begin{array}{c}\text { Rata-rata Waktu } \\
\text { (mnt) }\end{array}$ & Standar Beban Kerja \\
\hline 1 & Anamnese Pasien & 11,21 & 11132,39 \\
\hline 2 & pemeriksaan tanda vital pasien & 14,79 & 8438,43 \\
\hline 3 & Mengantar pasien ke ruang tindakan & 12,63 & 9880,00 \\
\hline 4 & Memasang gelang identitas & 13,16 & 9484,80 \\
\hline 5 & Menerima pasien baru & 11,79 & 10585,71 \\
\hline 6 & Nebulisasi & 13,00 & 9600,00 \\
\hline 7 & Fiksasi pasien & 12,11 & 10309,57 \\
\hline 8 & Pasang infus & 11,58 & 10778,18 \\
\hline 9 & Melepas infus & 15,32 & 8148,45 \\
\hline 10 & Melepas transfusi & 12,63 & 9880,00 \\
\hline 11 & Mengganti infus & 12,74 & 9798,35 \\
\hline 12 & Memperbaiki infus & 11,00 & 11345,45 \\
\hline 13 & Mendampingi visit dokter & 11,79 & 10585,71 \\
\hline 14 & Observasi pasien & 11,84 & 10538,67 \\
\hline 15 & Pemberian obat & 11,42 & 10927,19 \\
\hline 16 & Pasang monitor & 15,47 & 8065,31 \\
\hline 17 & Pasang NGT & 13,00 & 9600,00 \\
\hline 18 & Pasang Oksigen & 11,16 & 11184,91 \\
\hline 19 & Pemeriksaan EKG & 12,16 & 10264,94 \\
\hline 20 & Reposisi pasien & 12,47 & 10005,06 \\
\hline 21 & Reposisi selang oksigen & 11,32 & 11028,84 \\
\hline 22 & Membersihkan luka & 11,68 & 10681,08 \\
\hline 23 & Edukasi pasien & 15,11 & 8262,02 \\
\hline 24 & Menyiapkan perpindahan pasien & 12,89 & 9678,37 \\
\hline 25 & pasang kateter & 11,58 & 10778,18 \\
\hline 26 & pasang transfusi & 11,95 & 10445,81 \\
\hline 27 & Edukasi keluarga pasien & 13,21 & 9447,01 \\
\hline 28 & Membuang urine pasien & 10,63 & 11738,61 \\
\hline 29 & informed consent & 11,95 & 10445,81 \\
\hline 30 & Menyiapkan perpindahan pasien & 12,63 & 9880,00 \\
\hline 31 & Merapikan ruangan & 13,68 & 9120,00 \\
\hline 32 & konsul ke dokter jaga & 12,11 & 10309,57 \\
\hline 33 & Mengisi formulir skrining & 14,84 & 8408,51 \\
\hline 34 & Mengisi buku register & 13,53 & 9226,46 \\
\hline 35 & Persiapan alat & 12,63 & 9880,00 \\
\hline 36 & Merapikan meja & 12,63 & 9880,00 \\
\hline
\end{tabular}


Nadia Fajri, Yusni, Said Usman, Irwan Syahputra, Nurjannah: Analisis kebutuhan tenaga keperawatan berbasis beban kerja dengan metode workload indicator staff need (WISN) di instalasi gawat darurat (IGD) rumah sakit ibu dan anak Provinsi Aceh. Jurnal Kesehatan. Vol 13 (2) 2020

\begin{tabular}{rlrr}
37 & Operan shift & 11,74 & 10633,18 \\
38 & Mengisi rekam medis & 15,47 & 8065,31 \\
39 & Menyiapkan obat & 12,63 & 9880,00 \\
\hline 40 & Merapikan berkas tindakan & 12,84 & 9718,03 \\
41 & Merapikan troli emergency & 12,05 & 10354,59 \\
42 & Administrasi pasien pulang & 12,32 & 10133,33 \\
43 & Mengambil hasil ke radiologi & 12,37 & 10090,21 \\
\hline
\end{tabular}

Sumber : Data Diolah (2020)

\section{Menentukan Standar Kelonggaran Tenaga Keperawatan di IGD RSIA Provinsi Aceh}

Penyusunan standar kelonggaran tujuannya adalah diperolehnya faktor kelonggaran tiap tenaga perawat meliputi jenis kegiatan dan kebutuhan waktu untuk menyelesaikan suatu kegiatan yang tidak terkait langsung atau dipengaruhi tinggi rendahnya kualitas atau jumlah kegiatan pokok/pelayanan. Penyusunan faktor kelonggaran perawat dilaksanakan melalui wawancara mengenai faktor kelonggaran. Setelah faktor kelonggaran diperoleh selanjutnya menyusun standar kelonggaran sebagai berikut :

A. Waktu kerja tersedia : 2080 jam /tahun

B. Faktor kelonggaran : (contoh: pertemuan audit medik 2 jam/minggu, maka 2 jam $\mathrm{x}$ 52 minggu $=104$ jam/tahun)

C. Rumus standar kelonggaran :

$=104 \mathrm{jam} / 2080$

$=0,05$

\section{Menyusun Kebutuhan Tenaga Perawat}

Dalam WISN terdapat lima langkah yang diperlukan untuk menghitung jumlah perawat yang dibutuhkan yaitu :

1. Menentukan waktu kerja tersedia

2. Menentukan unit kerja berikut aktivitasnya

3. Menentukan standar beban kerja

4. Menyusun standar kelonggaran

5. Menghitung kebutuhan tenaga unit kerja

Keempat langkah untuk menghitung kebutuhan tenaga dengan metode WISN telah dijabarkan menurut variabel di atas, sedangkan langkah kelima yatu menghitung kebutuhan tenaga unit kerja disajikan dalam tabel berikut :

Tabel 5. Standar Kerja Tenaga Perawat di RSIA Provinsi Aceh

\begin{tabular}{clrrr}
\hline No & \multicolumn{1}{c}{ Kegiatan } & $\begin{array}{c}\text { Kuantitas } \\
\text { Kegiatan/tahun }\end{array}$ & $\begin{array}{c}\text { Standar Beban } \\
\text { Kerja }\end{array}$ & Kebutuhan \\
\hline 1 & Anamnese Pasien & 2914,74 & 11132,39 & 0 \\
2 & pemeriksaan tanda vital pasien & 3845,26 & 8438,43 & 1 \\
3 & Mengantar pasien ke ruang tindakan & 3284,21 & 9880,00 & 0 \\
4 & Memasang gelang identitas & 3421,05 & 9484,80 & 0 \\
5 & Menerima pasien baru & 3065,26 & 10585,71 & 0 \\
6 & Nebulisasi & 3380,00 & 9600,00 & 0 \\
7 & Fiksasi pasien & 3147,37 & 10309,57 & 0 \\
8 & Pasang infus & 3010,53 & 10778,18 & 1 \\
9 & Melepas infus & 3982,11 & 8148,45 & 1 \\
10 & Melepas transfusi & 3284,21 & 9880,00 & 0
\end{tabular}


Nadia Fajri, Yusni, Said Usman, Irwan Syahputra, Nurjannah: Analisis kebutuhan tenaga keperawatan berbasis beban kerja dengan metode workload indicator staff need (WISN) di instalasi gawat darurat (IGD) rumah sakit ibu dan anak Provinsi Aceh. Jurnal Kesehatan. Vol 13 (2) 2020

\begin{tabular}{|c|c|c|c|c|}
\hline 11 & Mengganti infus & 3311,58 & 9798,35 & 0 \\
\hline 12 & Memperbaiki infus & 2860,00 & 11345,45 & 0 \\
\hline 13 & Mendampingi visit dokter & 3065,26 & 10585,71 & 0 \\
\hline 14 & Observasi pasien & 4263,16 & 10538,67 & 1 \\
\hline 15 & Pemberian obat & 2969,47 & 10927,19 & 0 \\
\hline 16 & Pasang monitor & 4023,16 & 8065,31 & 1 \\
\hline 17 & Pasang NGT & 3380,00 & 9600,00 & 0 \\
\hline 18 & Pasang Oksigen & 2901,05 & 11184,91 & 0 \\
\hline 19 & Pemeriksaan EKG & 3161,05 & 10264,94 & 0 \\
\hline 20 & Reposisi pasien & 3243,16 & 10005,06 & 0 \\
\hline 21 & Reposisi selang oksigen & 2942,11 & 11028,84 & 0 \\
\hline 22 & Membersihkan luka & 5837,19 & 10681,08 & 1 \\
\hline 23 & Edukasi pasien & 3927,37 & 8262,02 & 1 \\
\hline 24 & Menyiapkan perpindahan pasien & 3352,63 & 9678,37 & 0 \\
\hline 25 & pasang kateter & 3010,53 & 10778,18 & 0 \\
\hline 26 & pasang transfusi & 4301,05 & 10445,81 & 0 \\
\hline 27 & Edukasi keluarga pasien & 4755,79 & 9447,01 & 1 \\
\hline 28 & Membuang urine pasien & 2764,21 & 11738,61 & 0 \\
\hline 29 & informed consent & 4301,05 & 10445,81 & 1 \\
\hline 30 & Menyiapkan perpindahan pasien & 3284,21 & 9880,00 & 0 \\
\hline 31 & Merapikan ruangan & 3557,89 & 9120,00 & 0 \\
\hline 32 & konsul ke dokter jaga & 3147,37 & 10309,57 & 0 \\
\hline 33 & Mengisi formulir skrining & 5343,16 & 8408,51 & 1 \\
\hline 34 & Mengisi buku register & 3516,84 & 9226,46 & 0 \\
\hline 35 & Persiapan alat & 4547,37 & 9880,00 & 1 \\
\hline 36 & Merapikan meja & 3284,21 & 9880,00 & 0 \\
\hline 37 & Operan shift & 3051,58 & 10633,18 & 0 \\
\hline 38 & Mengisi rekam medis & 5570,53 & 8065,31 & 1 \\
\hline 39 & Menyiapkan obat & 3284,21 & 9880,00 & 0 \\
\hline 40 & Merapikan berkas tindakan & 3338,95 & 9718,03 & 0 \\
\hline 41 & Merapikan troli emergency & 3133,68 & 10354,59 & 0 \\
\hline 42 & Administrasi pasien pulang & 3202,11 & 10133,33 & 0 \\
\hline \multirow[t]{4}{*}{43} & Mengambil hasil ke radiologi & 3215,79 & 10090,21 & 0 \\
\hline & Jumlah Yang dibutuhkan & & & 20 \\
\hline & Jumlah yang tersedia & & & 19 \\
\hline & Kekurangan & & & 1 \\
\hline
\end{tabular}

Sumber : Data Diolah (2020)

Berdasarkan perhitungan WISN diatas maka diketahui bahwa perawat yang dibutuhkan di IGD RSIA adalah 20 orang dengan jumlah yang tersedia saat ini adalah 19 orang terjadi kekurangan perawat sebanyak 1 orang.

\section{Pembahasan}

Hasil penelitian menunjukkan bahwa rata-rata waktu yang diperlukan untuk melakukan kegiatan langsung adalah 6.870 menit (55,9\%), kegiatan tidak langsung 3.448 menit $(28, \%)$, kegiatan pribadi 1.099 menit (8,9\%) dan untuk kegiatan non produktif 865 menit $(7,4 \%)$. Dari 
hasil perhitungan rata-rata waktu kerja terlihat bahwa jumlah waktu yang diperlukan oleh perawat sehari untuk menyelesaikan semua pekerjaan keperawatannya adalah 10 jam, hal ini tidak sesuai dengan UU ketenagakerjaan Pasal 77 ayat (2) UU Ketenagakerjaan Tahun 2003 yang menyebutkan bahwa waktu kerja adalah 8 (delapan) jam 1 (satu) hari dan 40 (empat puluh) jam 1 (satu) minggu untuk 5 (lima) hari kerja dalam 1 (satu) minggu.

Namun jika dikaji dari aspek uraian tugas maka itu adalah keseluruhan waktu yang diperlukan untuk melakukan semua uraian tugas seorang tenaga perawat, dalam pelaksanaannya tidak semua kegiatan tersebut dilakukan sehingga waktu yang diperlukan juga tidak mencapai jumlah tersebut tadi. Hasil penelitian ini sejalan dengan penelitian yang dilakukan oleh (Irnalita, 2008).

Sementara itu beban kerja seorang perawat dalam melaksanakan tugasnya sangat tergantung dari jumlah pasien. Secara teori disebutkan bahwa beban kerja seorang perawat sangat dipengaruhi oleh beberapa faktor antara lain :

a. Jumlah tenaga perawat. Menurut (1) permasalahan yang sering muncul di rumah sakit salah satunya adalah tidak seimbangnya beban kerja perawat. Sering kali manager sulit untuk mengetahui kualitas beban kerja karena lebih mendasar pada keluhan-keluhan yang bersifat subyektif. Situasi tersebut biasanya diawali dari tahap perencanaan kebutuhan tenaga perawat tidak sesuai dengan kapasitas kerja suatu suatu institusi pelayanan kesehatan.

b. Kondisi lingkungan kerja. Lingkungan kerja dapat yang menjadi sumber beban kerja antara lain tuntutan kerja, tanggung tuntutan kerja, hubungan antara perawat dengan tanggung jawab kerja, hubungan antara perawat kurang kurang baik.

c. Kepemimpinan. Menurut (9) kepemimpinan juga harus dapat mengkoordinasi lingkungan kerja serta yang kondusif dan dinamis serta merencanakan pengembangan karir perawat dengan cara aktif. Memotivasi perawat menjadi perawat yang baik dan mempunyai pandangan ke depan sehingga meningkatkan profesional mereka.

d. Tanggung jawab perawat Tanggung jawab perawat baik itu terhadap pasien sendiri maupun pasien perawat lain. Bekerjasama dengan perawat yang baru di ruang tertentu, atau perawat yang baru lulus dapat menambah beban kerja perawat lain, bisa juga dikarenakan marasa turut bertanggung jawab terhadap keselamatan pasien yang sedang ditangani perawat baru tersebut.

Berdasarkan hasil pengamatan penulis maka faktor yang mempengaruhi beban kerja perawat di RSIA Provinsi Aceh adalah karena kurangnya jumlah perawat yang tersedia. Berdasarkan perhitungan WISN diketahui bahwa perawat yang dibutuhkan di RSIA adalah 156 orang dengan jumlah yang tersedia saat ini adalah 127 orang terjadi kekurangan perawat sebanyak 29 orang.

Kekurangan tenaga perawat tersebut berdampak pada tingginya beban kerja yang harus ditanggung oleh seorang perawat pada jam kerjanya. Untuk itu agar pelayanan di RSIA Provinsi Aceh tetap berjalan dengan baik diperlukan penambahan tenaga perawat.

\section{Kesimpulan dan Saran}

\section{Kesimpulan}

1. Beban kerja tenaga kesehatan di RSIA Provinsi Aceh dapat dilihat dari rincian / uraian tugas jabatan, jumlah waktu yang dibutuhkan setiap tugas, waktu Penyelesaian Tugas merupakan perkalian beban kerja dengan norma waktu dan jumlah jam waktu kerja efektif. Beban kerja tenaga kesehatan selain dipengaruhi oleh jumlah tenaga juga dapat dipengaruhi oleh jumlah pasien dan kondisi lingkungan tempat kerja

2. Hasil perhitungan WISN diketahui bahwa tenaga kesehatan di RSIA Provini Aceh masih kekurangan 1 tenaga perawat di ruang IGD. Kekurangan tenaga kesehatan akan berdampak pada tingginya beban kerja tenaga kesehatan di masing-masing bidang 


\section{Saran}

1. Penelitian ini dapat memberikan masukan kepada ilmu pengurusan administrasi pegawai, khususnya dalam bidang beban kerja tenaga kesehatan .

2. Penelitian ini dapat menjadi sebuah masukan kaitannya dengan kebijakan kebutuhan medis dalam upaya optimalisasi pelayanan kesehatan di RSIA Banda Aceh

\section{Daftar Pustaka}

(1) Ilyas, Y. (2012). Kinerja, Teori, Penilaian dan Penelitian. Jakarta: Pusat Kajian Ekonomi Kesehatan FKM Universitas Indonesia.

(2) Kemenkes. (2016). Nomor 1691 Tahun 2011 Tentang Keselamatan Pasien Rumah Sakit. Jakarta: kemenkes RI.

(3) Siswanto, B. (2019). Pengaruh Motivasi Kerja Dan Disiplin Kerja Terhadap Kinerja karyawan. urnal Ilmiah Manajemen Sumber Daya Manusia.

(4) Setyawan, F. (2019). Manajemen Rumah Sakit. Jakarta: Zifatama Jawara.

(5) Ullatifa, N. (2017). Analisis Kebutuhan Tenaga Perawat Berbasis Beban Kerja DalamUpaya Meningkatkan Kualitas Pelayanan Pasien. Jurnal manajmen Kesehatan.

(6) Rubbiana, N. I. (2015). Analisis Beban Kerja Dan Kebutuhan Tenaga Perawat Pelaksana Dengan Metode Workload Indicator Staff Need (Wisn) Di Instalasi Rawat Inap Tulip RSUD Kota Bekasi Tahun 2015. Manajemen Pelayanan Kesehatan.

(7) Aubart, F. C. (2018). Workload, well-being and career satisfaction amongFrench internal medicine physicians and residents in2018. Careers in French internal medicine.

(8) Ningrum, R. K. (2019). Analisis Kebutuhan Perawat Pelaksana Berdasarkanmetode Workload Indicator Staff Need (Wisn) Dalam Upaya Meningkatkan Kualitas Pelayanan Diinstalasi Gawat Darurat Lantai I Rsup Dr Hasan Sadikin Bandung. Magister Manjemen.

(9) Kurniasari, A. P. (2017). Analisis Beban Kerja dan Kebutuhan Tenaga Perawat Menggunakan Workload Indicator of Staffing Need. Universitas Brawijaya. 